\title{
An Investigation of Classroom-Library Relationships on a College Campus as Seen in Recorded Circulation and GPA's
}

The study is an analysis of the library habits of the students of a small liberal arts college with emphasis on library-classroom relationships as revealed through comparison of library use and grade point averages. Expanded circulation records were kept on individual students in relation to the particular courses being taught at the time, in order to get per-capita circulation figures by both individuals and the courses for which the books were used. These figures were correlated with individual student grades and with instructor grading patterns by courses. Motivations for library use were also checked. Correlation between library use and GPA proved to be very low, since grading criteria and teaching methods did not take account of the sort of values that are normally achieved through library use.

$\mathrm{T}$

I His study was conducted at Grand Canyon College, Phoenix, Arizona, during the 1963/64 academic year. Grand Canyon is a church-related four-year college of arts and sciences with a fall enrollment in September 1963 of 479 students. The college was young and had not as yet been able to exercise much selectivity in its admissions procedures, attracting therefore a student body of average academic aptitude. Neither had it yet been able to achieve full regional accreditation by the North Central Association of Schools and Colleges. However, its teacher education program was approved by the Arizona State Board of Education, and therefore more students majored in education than in any other department and upon graduation, if qualified, were granted elementary or

Mr. Ritter is Librarian of Westmont College in Santa Barbara, California. secondary credentials. Although students of all faiths were freely admitted, the program was strongly promoted among and geared to the needs of college-age young people of its own denomination. The college's dormitories were always filled to capacity, but being located in a metropolitan area of several hundred thousand people, many students also commuted. At the time of this study 24 per cent of the student body were living in college housing.

\section{Problem and Method}

The study grew out of the desire of the college to bring its work to the highest possible point academically in order to achieve its goal of making possible a top-level liberal arts education for those who elect to come there, and as a byproduct, to attain the regional accreditation necessary to serve best the needs of its students and constituency. 
It is generally conceded that a college library can occupy a key place in any academic program if it is properly integrated into that program. It is also recognized that there can be a sizeable gap between this ideal and actual practice. Moreover, the existence of such a gap can sometimes go unrecognized by the faculty in its preoccupation with the other activities of the classroom. It was the purpose of this study therefore to develop and apply a technique for assessing the extent to which the library was actually attaining its full potential in the college's academic program.

The need was made even more apparent when the librarian (since moved to another college) in early 1964 conducted a survey of recorded library use for all the small accredited four-year liberal arts colleges in the United States. ${ }^{1}$ This survey revealed a national average of 46.1 loans per capita for $1962 / 63$, while the local college library had a recorded circulation figure (including both reserve and two week loans) of only 27 per capita. This ranked the college library fourteenth from the bottom of the list of ninety-two colleges, i.e., there were only thirteen accredited colleges which occupied a lower position.

Hypothesis. Through numerous studies of library use made in liberal arts colleges, it has generally come to be agreed that the key to extensive use of the library on the part of students is the manner in which the instructors organize and teach their respective courses. Whatever other factors may have a part, the crux of the matter lies in the classroom rather than in the library itself. The testing of this hypothesis (with an isolation and evaluation of factors causing the gap between classroom and library) lies at the heart of the present investigation. It

\footnotetext{
1 R. Vernon Ritter, "Recorded Library Use in Small Four-Year Colleges, 1962-1963," CRL, XXV (September 1964), 391-92.
}

is conceivable that in an isolated college situation, this hypothesis, although arrived at through numerous studies of liberal arts college library situations, might nevertheless be inapplicable in some particular case due to special or unusual circumstances.

Other Studies of Library Use. The problem of method remained to be solved. There have been several significant and very useful techniques developed by various investigators beginning with Harvie Branscomb's notable work in $1937-39^{2}$ up to the most recent at the University of Delaware as reported by Gorham Lane. ${ }^{3}$ Quoting from the introductory paragraph of the latter study:

Although the University Library is regarded consensually as a potent educational force, its strength is more often than not described in terms of its physical facilities, the extent of its collections, or even its budget. . . . These do not provide a measure of the library's effectiveness as an instrument of education. Such measures can be obtained only by assessing the extent to which students use the library and the extent to which such use relates to academic growth. These assessments are not easy.

The present study is an attempt to use the techniques of other investigators but with three significant additions: (1) The correlation of book use with faculty evaluations of course work as represented by grades, and this computed both individually and by courses; ${ }^{4}$ (2) By means of a questionnaire arrive at some estimate of off campus library use; (3) Also by means of a questionnaire, to arrive at

2 B. Harvie Branscomb, Teaching with Books; a Study of College Libraries (Chicago: Association of American Colleges, ALA, 1940). Cf. also Patricia B. Knapp, College Teaching and the College Library (Chicago: ALA, 1959).

3 Gorham Lane, "Assessing the Undergraduates' Use of the University Library," CRL, XXVII (July 1966), 277-82.

4 Lane evidently did figure his statistics for this, but made nothing of it except to note the lack of clear correlation. Ibid., p.280-81. Perhaps this lack of correlation is itself significant! 
some estimate of the relative importance of various motives for library use or lack of use.

The nine weeks (exactly half of the semester) just before Christmas vacation in the school year 1963/64 were chosen as a representative and easily handled period for study. The first step was to expand circulation records so as to get more highly individualized data than normal procedures provided. A record was kept of the number of books checked out by each student, as well as a record of the courses for which they were to be used.

The student totals were ranked in order of the number of books used and both median and average figures determined from the list. Grade point averages $^{5}$ for each student were secured from the registrar's office and used to ascertain whether or not there was any correlation between grades and number of books used. This was supplemented by taking a mean of the grade point averages for those making no use of the library and another mean for those at the top of the list who made heaviest use of the library.

The instructors' semester grade reports were used to determine the number of students enrolled in the courses. Net enrollment was figured by subtracting all withdrawals. This net figure was used to get average per-student circulation in each course. The same grade reports provided figures for computing the grade point average for each course. This gave another opportunity for comparing grades and books used, this time in relation to each instructor's course.

To supplement the data collected and to aid in its interpretation, a questionnaire was developed and mailed out

Grand Canyon College uses a 3 point rather than a 4 point system in computing its grade point averages. The valuations are as follows: $A=3.0 ; B=2.0$; $\mathrm{C}=1.0 ; \mathrm{D}=0.0 ; \mathrm{F}=-1.0$. which would bring to light the extent of the use of off-campus library resources. The latter was especially important in view of the large proportion of the students who commuted. The questionnaire also sought to determine motives either for heavy or light book use. It was sent to the seventy-five heaviest users of of the library (the fifteen top users in each class: freshman, sophomore, junior, senior, and special). Also it was sent to the 150 students who showed no recorded use of the library for the whole nine weeks.

The last step in the investigation involved the tabulation and interpretation of the results.

It is recognized that a completely controlled situation cannot be created for such a study as this, and that some room must be left for a margin of error resulting from the intrusion of incommensurable or unrecognized factors that may to some extent skew the results. However, certain safeguards were set up. The fact that the study was in progress was not revealed to either students or faculty lest conscious or unconscious deviations from typical patterns of action should creep in. Questions from borrowers as to the reason for the extra information about the identification of courses for which books were being used were parried with a stereotyped noncommital answer: "We are making a special study of the library for accreditation purposes." The questionnaires which were returned unsigned were sent out after all other statistics were gathered.

\section{Results}

Distribution of Book Use by Students. The total student circulation for the semester was 5,491; the total for the nineweek test period (October 19 to December 20) was 3,182 , or 58 per cent of the whole. If there is any skewing of the picture, therefore, it would be in the 
direction of making the situation look better than it really is.

Elimination of all auditors and those who withdrew from school without completing the full semester's work reduced the number on whom computations were made from the initial 479 to 468 . Table 1 gives the circulation statistics for these 468 students.

Summarizing Table 1-

468 students checked out a total of 3,181 books.

Median per capita, 3 books.

Mean per capita, 6.7 books.

The lowest 50 per cent of the students checked out 157 books or 4.9 per cent of the total.

The highest 50 per cent of the students checked out 3,024 or 95.1 per cent of the total.

The top 13 per cent of the students were responsible for 50 per cent of the loans.

The top 5 per cent of the students were responsible for 24.3 per cent of the loans.

It will be noted that the average per capita figure is considerably larger than the median. In statistics of this sort the median is usually considered to be the more significant figure. The average is much higher as a result of a few students checking out a large number of books and so distorting the over-all picture. With the lowest 50 per cent of the students checking out only 4.9 per cent
TABLE 1. Recorded Circulation by Students, Ranked in Order of Book Use

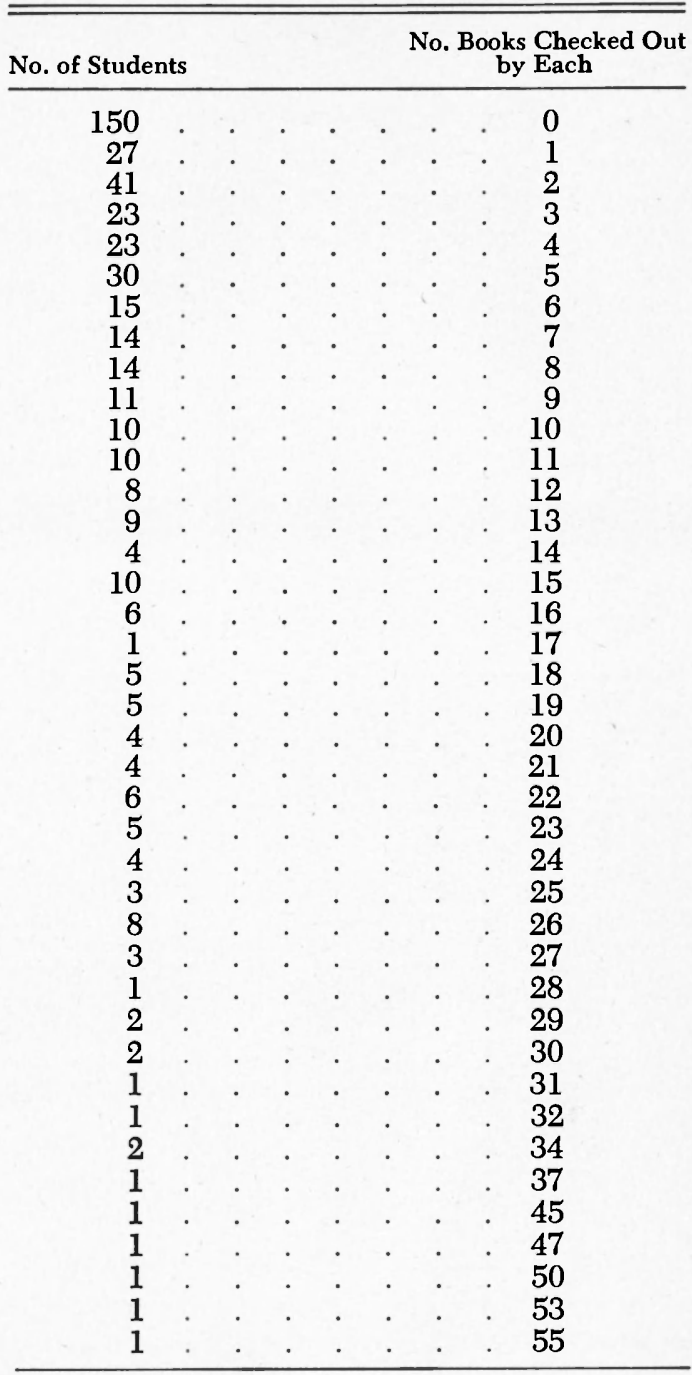

TABle 2. Recorded Circulation in Relation to GPA

\begin{tabular}{c|l|c|c}
\hline \hline $\begin{array}{c}\text { Number of } \\
\text { Students }\end{array}$ & \multicolumn{1}{|c|}{ Grouped by Library Use } & $\begin{array}{c}\text { Average } \\
\text { GPA }\end{array}$ & $\begin{array}{c}\text { Per Cent of Total } \\
\text { Circulation }\end{array}$ \\
\hline 150 & $\begin{array}{l}\text { No recorded use of library } \\
\text { Lowest use below median } \\
(1-3 \text { vol. each) } \\
\text { Lowest use below median } \\
(3-7 \text { vol. each) }\end{array}$ & 1.43 & 4.9 \\
84 & $\begin{array}{c}\text { Highest use } \\
\text { (7-55 vol. each) } \\
150\end{array}$ & 1.33 & 95.1 \\
468 & Whole Student Body & 1.47 & 100.0 \\
\hline
\end{tabular}


of the total the college could justifiably conclude that the library is making no significant contributions, so far as recorded circulation is concerned, to at least half of the student body.

Noting again the figures above-that the lowest 50 per cent of the students checked out only 157 books or 4.9 per cent of the whole, and the highest 50 per cent checked out 3,025 books or 95.1 per cent of the whole; it is rather surprising to discover that this very great difference is not paralleled by a comparable difference in GPA as revealed in Table 2.

This is the first indication of the fact that there may be a very low correlation between use of the library and the grades given. If true, it can only be concluded that in the judgment of the instructors as shown in the grades given, it is possible for a large portion of the students to do average work with no use of the library whatsoever.

If the students are grouped by classes, the circulation and GPA statistics come out as shown in Table 3.

The figures for both circulation and GPA show a steady and expected increase from the sophomore through the senior years. It is when we note the statistics for the freshmen and special students that we turn up the unexpected. These unusual results may be explained by the admissions policies in force.

As to special students:

1) they constitute an unusually large proportion of the student body: 16.3 per cent;

2) they are non-degree, part-time students taking only a few units each;
3) many already have college degrees, and are engaged in public education and taking a course or two at the college either from special interests or to enhance their professional standing; 4) they almost all live off campus.

These special factors probably account at least in part for both the low book use and the above-average GPA's.

The low GPA for the freshman class in spite of a fairly high record of circulation (it is above the sophomore level) probably results from an open admissions policy that allows the matriculation of a rather large percentage who are not capable of college level work in spite of evident effort as gauged by use of library materials. The resultant .98 GPA is .02 below the minimum level necessary to remain in school. The big difference between the size of the freshman and sophomore classes would suggest a high attrition rate resulting from a similar situation the previous year.

To get at the question of whether there was a causal relationship between the steady increase in GPA's from class to class as seen in Table 3 and the likewise steady increase in recorded per capita circulation, further analysis is attempted in Table 4. Average GPA's were computed for those in each class who made no use of the library and checked against the GPA's for an equal number in each class who made the heaviest use of the library.

In four out of five of the above groups a positive correlation does exist between book use and GPA. It is important to note though that with the exception of the sophomore class, it takes a major in-

Table 3. Recorded Per Capita Circulation by Classes in Relation to GPa

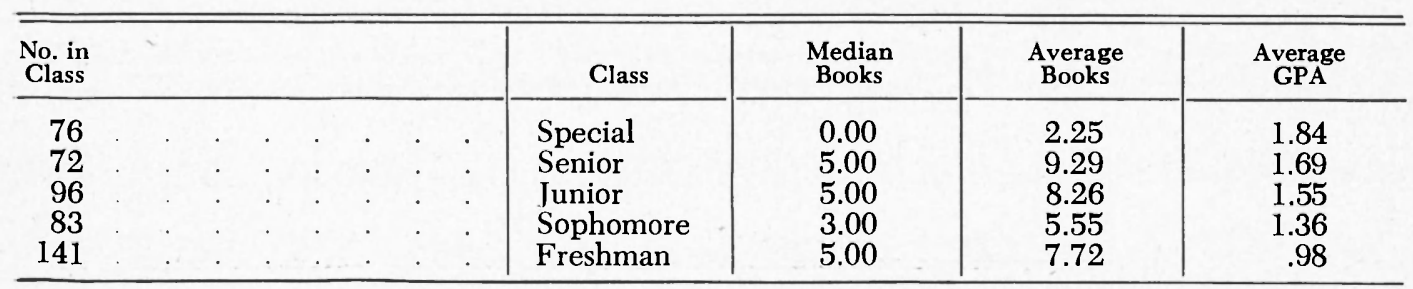


crease in book use to bring only a slight increase in GPA, and in the junior class the opposite is true. These two facts would seem to be particularly important in interpreting book use and GPA correlations. It would suggest other factors as being more significant than library use in causing increased GPA's when one moves from the freshman to senior year, e.g., the weeding out of poorer students as one moves up the academic ladder. Moreover, in three out of five of the groups those who made use of the library were able to get GPA's above the 1.43 average for the school as a whole. The instructors have in effect been saying by their grading standards: "The student can do above average work in large segments of the curriculum without recorded use of the library."

However, it could be that since this is an open stack library, students were making heavy use of materials in library reading areas which would never show in recorded circulation statistics. Various faculty members felt sure that this was actually happening. To get at the facts of the matter a survey of library activities was made on two separate occasions, the sixteenth week of the fall semester and the sixth week of the spring semester. During these two weeks a total of ninety-four hourly counts were made of the number of students studying in the library, including a record of whether or not they were using any library materials. The number present at one time av- eraged eighteen (3.1 per cent of the student body) for all counts; the highest at any one time was forty-four and on twenty occasions the number ranged from zero to nine. Even more revealing was the small proportion of this low number present who were actually using library materials-an average of 34.9 per cent; the other 65.1 per cent were using the library only as a study hall for reading their own books. ${ }^{6}$ Left, therefore, with an average figure of only six or seven students out of the total student body of 468 using library materials on the premises at any one time, it could hardly be claimed that the open stack facilities were significantly skewing the recorded circulation as a valid gauge of classroom-library relationships. This is especially true if it is remembered that the other colleges with which circulation statistics were being compared were nearly all open stack libraries.

There is one more loophole that could possibly invalidate the picture that is becoming increasingly clear. To what extent does use of outside library facilities modify the situation, especially for those who made no use of the college library? Do the large number of students who live off campus actually make extensive use of other libraries? To

${ }^{6}$ Details of this study are found in: R. Vernon Ritter, "An Evaluation of Fleming Library, Grand Canyon College," p.24-25 (Dittoed and distributed to Administration and Faculty, May 1, 1964).

TABLE 4. Average GPA's for Those Making No Use of Library and Those Making Highest Use

\begin{tabular}{|c|c|c|c|c|c|c|c|}
\hline \multirow[b]{2}{*}{ Crass } & \multicolumn{3}{|c|}{ No-Use Group } & \multicolumn{3}{|c|}{ Heaviest-Use Group } & \multirow{2}{*}{$\begin{array}{c}\text { GPA } \\
\text { INCREASE } \\
\text { ACHIEVED }\end{array}$} \\
\hline & $\begin{array}{l}\text { No. of } \\
\text { Students }\end{array}$ & $\begin{array}{l}\text { No. Bks. } \\
\text { Circulated }\end{array}$ & $\begin{array}{c}\text { Average } \\
\text { GPA }\end{array}$ & $\begin{array}{l}\text { No. of } \\
\text { Students }\end{array}$ & $\begin{array}{c}\text { No. Bks. } \\
\text { Circulated }\end{array}$ & $\begin{array}{c}\text { Average } \\
\text { GPA }\end{array}$ & \\
\hline $\begin{array}{l}\text { Freshman } \\
\text { Sophomore } \\
\text { Junior } \\
\text { Senior } \\
\text { Special }\end{array}$ & $\begin{array}{l}28 \\
25 \\
28 \\
15 \\
53\end{array}$ & $\begin{array}{l}0 \text { each } \\
0 \text { each } \\
0 \text { each } \\
0 \text { each } \\
0 \text { each }\end{array}$ & $\begin{array}{l}.89 \\
1.10 \\
1.62 \\
1.57 \\
1.72\end{array}$ & $\begin{array}{l}28 \\
25 \\
28 \\
15 \\
23\end{array}$ & $\begin{array}{r}15-37 \text { ea. } \\
6-32 \text { ea. } \\
11-55 \text { ea. } \\
16-53 \text { ea. } \\
1-25 \text { ea. }\end{array}$ & $\begin{array}{l}1.04 \\
1.62 \\
1.57 \\
1.83 \\
2.14\end{array}$ & $\begin{array}{l}+.15 \\
+.52 \\
-.05 \\
+.26 \\
+.42\end{array}$ \\
\hline
\end{tabular}


36 / College b Research Libraries • January 1968

TABLE 5. Distribution of Book USE by Courses

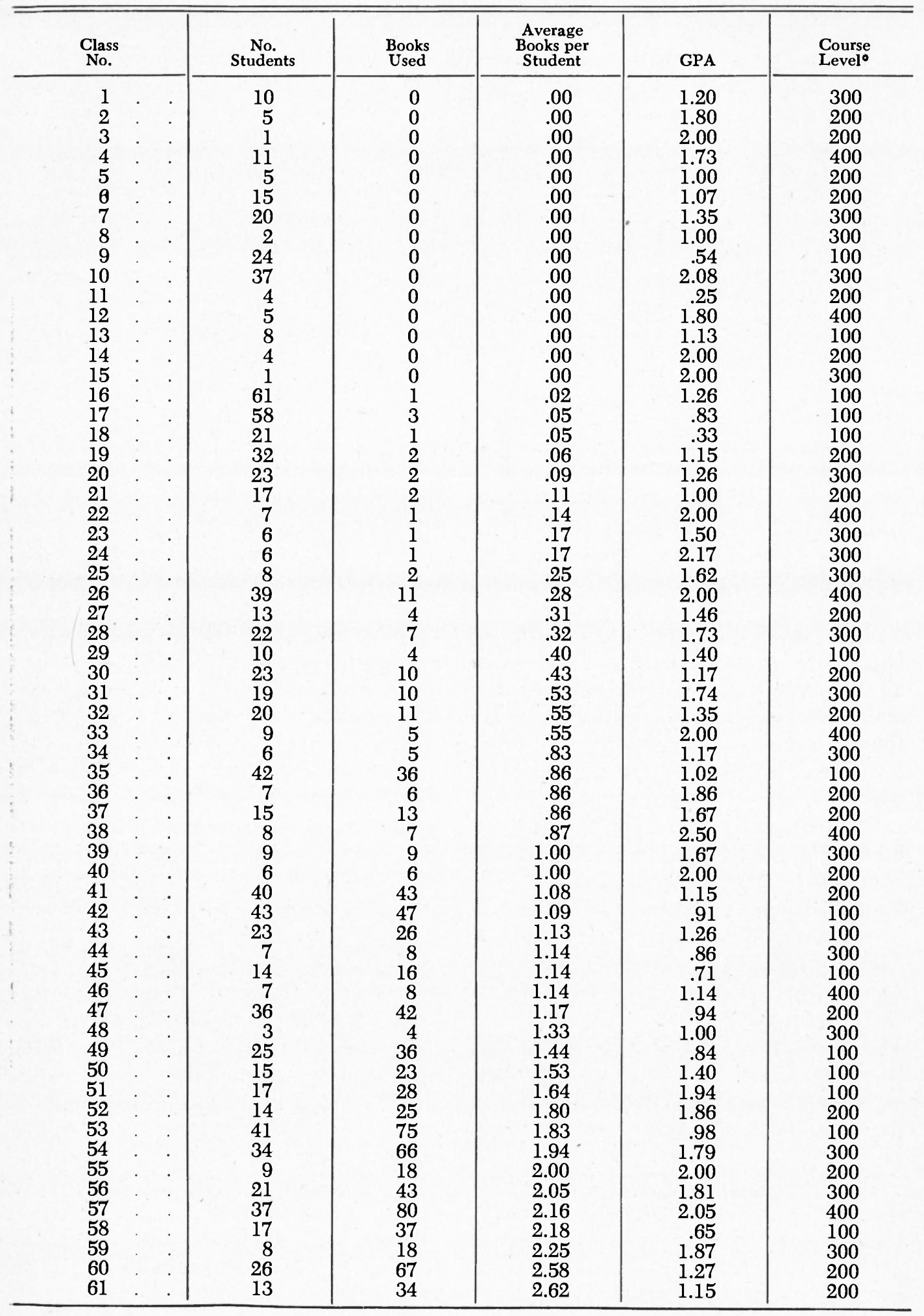


TABLE 5 (Cont.)

\begin{tabular}{|c|c|c|c|c|c|}
\hline $\begin{array}{l}\text { Class } \\
\text { No. }\end{array}$ & $\begin{array}{l}\text { No. } \\
\text { Students }\end{array}$ & $\begin{array}{l}\text { Books } \\
\text { Used }\end{array}$ & $\begin{array}{c}\text { Average } \\
\text { Books per } \\
\text { Student }\end{array}$ & GPA & $\begin{array}{l}\text { Course } \\
\text { Level }\end{array}$ \\
\hline $\begin{array}{l}62 \\
63 \\
64 \\
65 \\
66 \\
67 \\
68 \\
69 \\
70 \\
71 \\
72 \\
73 \\
74 \\
75 \\
76 \\
77 \\
78 \\
79 \\
80 \\
81 \\
82 \\
83\end{array}$ & $\begin{array}{r}9 \\
52 \\
10 \\
41 \\
9 \\
13 \\
31 \\
17 \\
2 \\
4 \\
9 \\
18 \\
12 \\
21 \\
19 \\
19 \\
31 \\
20 \\
17 \\
6 \\
9 \\
11\end{array}$ & $\begin{array}{r}24 \\
145 \\
28 \\
116 \\
26 \\
39 \\
101 \\
58 \\
7 \\
15 \\
34 \\
70 \\
47 \\
86 \\
92 \\
113 \\
204 \\
135 \\
155 \\
70 \\
117 \\
188\end{array}$ & $\begin{array}{r}2.67 \\
2.79 \\
2.80 \\
2.83 \\
2.89 \\
3.00 \\
3.26 \\
3.41 \\
3.50 \\
3.75 \\
3.78 \\
3.90 \\
3.92 \\
4.09 \\
4.84 \\
5.94 \\
6.58 \\
6.75 \\
9.12 \\
11.67 \\
13.00 \\
17.09\end{array}$ & $\begin{array}{r}1.89 \\
1.71 \\
1.30 \\
.49 \\
1.67 \\
1.38 \\
1.00 \\
1.71 \\
2.50 \\
2.22 \\
1.33 \\
.17 \\
2.50 \\
.90 \\
.52 \\
1.21 \\
1.58 \\
1.90 \\
1.76 \\
1.17 \\
2.00 \\
1.91\end{array}$ & $\begin{array}{l}300 \\
100 \\
400 \\
100 \\
300 \\
100 \\
100 \\
200 \\
400 \\
400 \\
300 \\
100 \\
300 \\
100 \\
100 \\
100 \\
200 \\
300 \\
300 \\
300 \\
300 \\
300\end{array}$ \\
\hline
\end{tabular}

- In general the course numbering system relates to whether the courses are primarily understood as freshman, sophomore, junior or senior courses; this is by no means adhered to in any rigid manner. There would be a clearer break between Lower Division (100 and 200) courses and Upper Division (300 and 400$)$ courses than there would be between the two levels within each division.

check this a questionnaire was sent to all 150 students making no use of the college library requesting information on the use actually made of other libraries. Forty-two out of the one hundred fifty were returned.

Of the forty-two responding:

6 made "much" (average 22 vol.) use of public libraries.

2 made "much" (average 15 vol.) use of college libraries (other than home college).

4 made "much" use of their own private collections.

The size of the home libraries ranged from five to fifteen hundred volumes with one hundred as the median sizehardly an adequate substitute for a public or college collection.

We have no way of knowing whether the 108 others making no use of Grand Canyon College library made extensive use of other libraries. However, it is probably safe to suppose that a large proportion of them did not return the questionnaires (return stamped envelopes had been enclosed) for the simple reason that they had nothing of other library use to report. Since only eight indicated "much" use of other college or public libraries, it seems fair to conclude also that the low use of this college library had not been replaced by significant use of other library collections.

\section{Distribution of Book USE by Courses}

It is generally agreed that there is very little virtue in library book use for certain types of courses. For that reason any increase in total library circulation would have to be developed within those courses where library use could conceivably be valuable (or in general interest circulation). For this reason the courses in elementary languages, music, mathematics, physical education activities, and such were excluded from the main group of courses. 
TABLE 6. BoOK Use aNd GPA CoMpared When Courses Are Grouped at VARIOUS COURSE LEVELS

\begin{tabular}{|c|c|c|c|c|}
\hline $\begin{array}{c}\text { Course } \\
\text { Level }\end{array}$ & & $\begin{array}{c}\text { No. of } \\
\text { Courses }\end{array}$ & $\begin{array}{l}\text { Aver. Bks. } \\
\text { per capita }\end{array}$ & $\begin{array}{c}\text { Average } \\
\text { GPA }\end{array}$ \\
\hline 100 series & & 23 & 1.91 & .99 \\
\hline 200 series & . & 22 & 1.16 & 1.43 \\
\hline 300 series & . & 27 & 3.07 & 1.63 \\
\hline 400 series & . & 11 & 1.38 & 1.93 \\
\hline
\end{tabular}

Since among the courses listed in Table 5 there is variation in the value of library book use even in an ideal situation, it would be inappropriate to make too much of individual applications. However the following comparisons may be made:

1. Comparing the two extremes of per capita book use in the various courses, fifteen courses that made no use of the library achieved an average GPA of 1.40 , only .03 less than the school average; at the other extreme the fifteen highest users ranging from 3.41 to 17.09 volumes per capita achieved an average GPA of 1.56 , only .13 above the school average of 1.43 .

2. When all the classes are compared -the lowest per capita book users with the highest-the lowest half achieved an average GPA of 1.45 as against a 1.42 for the highest!

Table 6 gives the statistics from Table 5 redistributed by course level. The results are in harmony with what would be expected from the analysis of book use and GPA's by classes (supra), and introduce no new variants.

The analysis of book use by courses confirms the previously tentative con- clusion: for large areas of the curriculum it is possible to get above average grades with little or no use of the library. Or to put it in other terms: in the opinion of the instructors, judged by the grades given, good work can be done in a sizeable portion of the curriculum with only negligible use of the library.

\section{Student Motivation}

Question 2 of each of the two questionnaires, one sent to the 150 nonlibrary users, and the second sent to the 75 heaviest users of the library, was an attempt to rate motives for library use, or lack of use. The results are tabulated in Table 7 with an indication of the number of students who considered each motive as being of first, second, third, or fourth place importance in prompting to library use.

As might be expected, the classroom stands out as of supreme importance for motivating the use of the library whether by way of formal requirements or by way of subject interest. However, there is considerable indication that those who used the library most went beyond classroom requirements or on the basis of special subject interest, or on the basis of previously established study habits. Seventeen rated this as of first or second place importance. In effect these would be saying: "Whatever course requirements may have been, whether great or small, we study and use libraries this way in any case."

The importance of this point in this particular academic situation stands out in Table 8, which shows the results of

TABLE 7. Student Motives for Library Use Among Heavy Users

\begin{tabular}{|c|c|c|c|c|}
\hline Reason & First Place & Second Place & Third Place & Fourth Place \\
\hline $\begin{array}{l}\text { Previously established study habits } \\
\text { Course organization and requirements } \\
\text { Greater than average interest in particular } \\
\text { courses taken at time of survey } \\
\text { Recreational Reading }\end{array}$ & $\begin{array}{r}2 \\
27 \\
7 \\
1\end{array}$ & $\begin{array}{r}15 \\
7 \\
9\end{array}$ & $\begin{array}{r}14 \\
3 \\
15\end{array}$ & 2 \\
\hline
\end{tabular}


TABLE 8. Student Motives for Library Use Among Low Users

\begin{tabular}{c|c|c|c|c}
\hline \hline Reason & First Place & Second Place & Third Place & Fourth Place \\
\cline { 2 - 5 } $\begin{array}{l}\text { No need for much use because of nature } \\
\text { of course requirements }\end{array}$ & 25 & & & \\
Much use of library materials elsewhere & 11 & 5 & 2 & 2 \\
Inadequacy of college library & 2 & 5 & 1 & 6 \\
Procrastination & 4 & 3 & 10 & 4 \\
\hline
\end{tabular}

the other questionnaire sent to those who made no recorded use of the library; there it becomes clear that those who do not have such study habits and whose particular courses do not require extensive use of the library, end up with no recorded library use. By far, the greatest portion of those who show no recorded library use claim that their courses did not require it. This could be an idle rationalization, but a check of their GPA's confirmed this claim in 75 per cent of the cases (Table 9). None were below 1.00 ; all but five were above the 1.43 average for the student body as a whole. The five who rated this lack of need as of second importance had GPA's as follows: $1.20 ; 1.33 ; 2.00 ; 2.00 ; 2.00$.

It can only be concluded therefore that, in the opinion of their instructors, these students were able to do above average work in spite of their lack of library withdrawals.

In regard to the reason getting the second largest number of votes: "much" use of libraries elsewhere (including their own private collections), the following should be noted:

1. Out of the 42 responses, the proportion of those not using their own college library, but who claim "much use of other libraries" harmonizes with the facts already discovered from the analysis of the first half of the questionnaire: 12 out of 42 -they would both be approximately 30 per cent.

2. A check of use made of other libraries by those who also made heaviest use of their college library reveals that
50 per cent in this group claim "much use" of other libraries.

The comparison of these two groups suggests a rather strong tendency for other library use to follow the pattern of local college library use. If they use the local college library more, they use other libraries more; if they use the local college library less, they use other libraries less. The one is a replacement for the other only to a very small degree.

\section{ConClusion}

Although it was not possible to set up laboratory-like controls or use a scientifically accurate statistical procedure, it has been possible to isolate factors relevant to the problem of an admittedly low circulation figure, and to point out certain tendencies, as well as strengths and weaknesses inherent in the classroom-library relationships of this particular college campus. Even though the statistics assembled derive from only one college, they do have implications for other institutions as well, and might merit careful consideration by the administration and faculty of other schools. Although this particular college is unaccredited, its circulation statistics were being compared with those of fully accredited institutions only, and there were thirteen others that were lower! If we arbitrarily add to those the figures for the thirteen immediately above (who did not really do much better, ranging from 27.6 to 31.7 per capita) it can be readily seen that the campus surveyed is hardly altogether atypical! 
TABLE 9

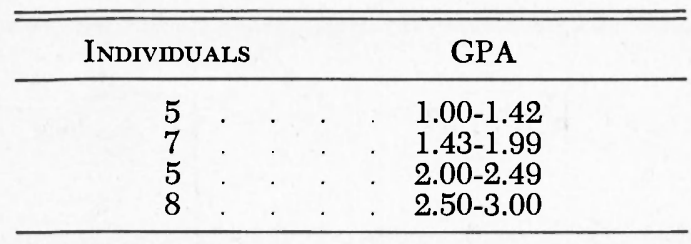

After approaching the questions investigated both through individual students and courses of study, it is clear that all lines converge upon the classroom as the main determinant. The gap between library and student can be bridged only by bridging the gap between classroom and library. The extent to which the instructor can generate a thirst for learn- ing, can communicate something of the excitement of ideas, and can share with inquiring minds his own very genuine enthusiasm in his search for truth-these very personal factors are crucial. It is the contagion of such enthusiasm that catches on-there is no known substitute. It must be humbly admitted that this investigation has served only to point up the greatness of the problem by underlining the formal and the commensurable. The real solutions can only come by way of the intangible and interpersonal. It is the glory of the small college that it still has room, and time, and concern for such values.

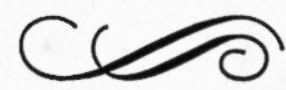

